\title{
On Transnational Strategic Performance Management of Firm Based on Synergy of Organizational Learning
}

\author{
Deyun Xiao Xiangfang Zhu Weibao Li
}

College of Economics, Wuhan University of Technology, P. R. China

\begin{abstract}
Performance measurement experienced stage of financial measurement, stage of value management measurement and stage of combination of financial measurement and non-financial measurement. Introduction of OL(organizational learning) to performance management can strengthen implementation of strategy and then raise efficiency of performance management. Combined with three typical transnational patterns of electrical home appliances enterprise of China, Haier, TCL and Galanz. The paper built performance management model with synergy of single loop learning and performance management model with synergy of double loop learning and organizational learning performance management system model as well as multistage transnational performance measurement system with synergy of organizational learning which includes four stages that is stage of domestic management, stage of multinational management, stage of transnational management and stage of global management.
\end{abstract}

Keywords: Transnational Operation, OL, Performance Management

\section{Introduction}

Performance management is important tool for strategy control, and offers firm interaction control and diagnosis control [1] (Simons, 1991). Performance management with synergy of organizational learning means that firstly performance measurement including measures of organizational learning, for example Balance Scored Card including measures of learning and growth and part $\mathrm{B}$ of KBEMS organization excellence is focus of process excellence, organizational learning and stakeholder, and secondly as tool of strategy control, synergy of organizational learning and performance strengthen strategy control of firm ${ }^{[2]}$. Kostas $(2004)^{[3]}$ argues that performance measurement as tool for performance diagnosis and performance improvement should take organizational learning into performance operation and performance measurement design.

\section{Model of Performance Management with Synergy of OL}

Single loop learning ${ }^{[4]}$ is dynamic process tracing and adjustment of key measures during performance management to raise efficiency of strategy implementation through interaction control and diagnosis control. Performance management model adopting PDCA cycle is with process of strategy goal, strategy performance plan, strategy plan implementation, strategy evaluation and strategy promotion showed as Fig.1. Early development of electrical home appliances enterprise of 
China achieved good performance by using mainly single loop learning. Haier introduced equipment and technology of German in 1985 to produce refrigerator. Haier obtained market performance by focusing quality management. In 1992 Galanz invested 3 million dollars to introduce international advanced production line and technology of microwave oven from Panasonic Corporation. In $1985 \mathrm{TCL}$ and TTK of Hong Kong built joint venture to enter into industry of telecommunication equipment and got good performance.

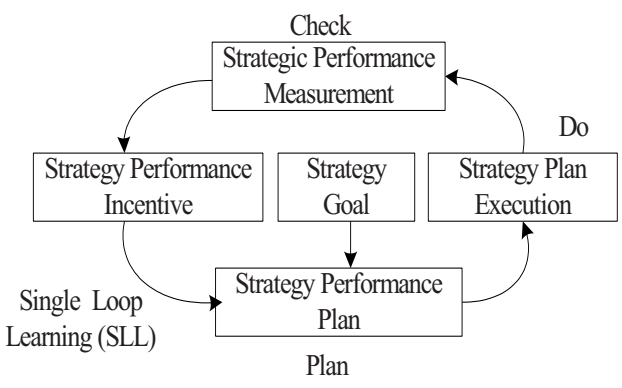

Fig. 1: Performance management control model based single loop learning.

Double loop learning ${ }^{[10]}$ evaluate efficiency of strategy implementation and build new strategy goal according to environment change and then follow the process of single loop learning to implement interaction control and diagnosis control of enterprise as in Fig 2. Early success of Haier, TCL and Galanz made them accumulate plentiful experience and form management system that was basis for organizational learning and achievement of new strategy goal. Haier and TCL achieved diversification strategy, Haier successively merged 18 enterprises to march into industry of air conditioner, washing machine and color TV through eating "shock fish" to implement diversification strategy from 1992 to 1998 . In 1992, TCL entered the color TV industry, in 1998, TCL began with personal computer to enter into the IT industry, enter into terminal field of the cell-phone in the same year, in 1999, the research center of air conditioner was established, adopted OEM(Original Equipment manufacture) to produce air conditioner. Galanz has produced nearly over one hundred kinds of products about microwave oven, and entered into small electrical home appliances industry, such as the electric cooker and electric fan, etc. In 2000, Galanz marched into industry of air conditioner.

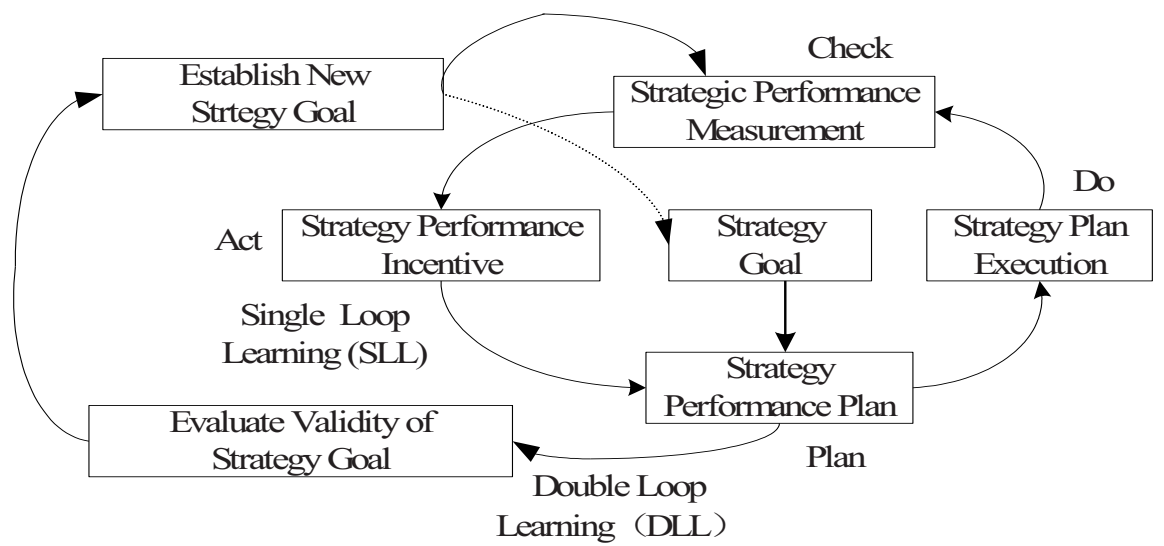

Fig. 2: Performance Management Model Based on Double Loop Learning. 


\section{Mechanism of Performance Management with Synergy of OL}

\subsection{Strategy Goal Setting with Synergy of OL}

Strategic objective is based on recognition of environment. Performance measurement like indicator of running vehicle that change of strategic environment bring new opportunity for development to enterprise, for instance, enormous progress of science and technology, and cause enterprise's strategy goal established originally not to adapt to the change, so new strategic objective must be launched. In the course of starting new strategic goal, it is a foundation of starting the new strategic goal that effective recognition of the strategic environment by organization learning, Enterprise's perfect organizational learning system is a prerequisite of high-efficient processing of environmental information of the strategy. Each employee is nerve endings of organizational Learning. Openness is important condition of organizational Learning, the system has higher openness, when difference that can't be confirmed occurred, organization learning makes organization communicate about difference enough, thus effective environmental information of strategy can be obtained. At the same time decision localization with higher degree organization learning had makes employees can effectively process the change of information of strategic environment of external world, just as honeybee going out to pick honey continues collecting and exchange information of new pollen source.

\subsection{Performance Management Network System of OL Based on Strategy Goal Set}

Process of organizational learning can be classified into information acquisition, information dissemination, information interpretation and organizational memory (Huber, 1991) ${ }^{[5]}$. First organization learning can take place among subsidiaries and parent company. Information sharing is important guarantee for success of transnational corporation to raise utilization efficiency of knowledge. Second organizational learning can take place between Strategy Business Unit (SBU). Organizational learning obtains useful information by recognition of environment. Haier found that the washing machine does not sell well in summer, After the reason that there is less clothes in summer to be found, Haier developed the washing machine of "Xiao Shen Tong" with small volume. Organizational learning can be divided into individual learning, group learning and organization learning in different level. Individual learning is basal unit of organizational learning. Leaders of enterprises are the pusher who organizes organizational learning, Zhang Ruimin, director of Haier, Liang Qingde, director of Galanz, and Li Dongsheng, director of TCL, they have sharp insight and innovative spirit and advance organizational learning. Function of diagnosis control and interaction control of performance management can get better execution result through organizational learning. Model of performance management with synergy of organizational learning shows as Fig. 3. Performance improvement of operator by organizational learning advances performance improvement of process and of organization. Organizational learning can be strengthened during performance improvement and core competence is formed by abundant knowledge of experience got through organizational learning. The mission and values is engine driving performance improvement. 
Processing of strategy information got through organizational learning can form strategic goal of enterprises. Goal of performance improvement can be formed according to strategy goal of one stage. Organizational learning system can be formed through forming of strategy goal. Strategy goal of one stage can be decomposed into goal of SBU. Performance goal of process, performance goal of department and fulfillment of department, then is formed. Performance goal of individual permeate organizational learning system. Performance goal of process, performance of individual and fulfillment of individual further can be decomposed into performance goal of individual. By insight of strategic environment, Haier confirmed management objectives of product quality. Haier smashed 76 refrigerators not up to standard in public in 1985 that promoted organizational learning mechanism for quality control inside organization. Management system of Overall Every Control and Clear (OEC) of Haier improved performance of operator and further improved performance of process. OEC improved performance of Haier and its fulfilment of all level. TCL attached emphasis to training and organizational learning very much. Demand of training is produced from bottom to top. Galanz took the lead in firing the price war in 1996. It succeeded in implementing low cost strategy and specialized strategy that is process of performance management with synergy of organizational learning, such as research and development. Before 1997, Galanz mainly take technology introducing and digesting as the focal. It introduced the production line and technology of Toshiba since 1992, and introduced the most advanced microwave oven production equipment and technology by 1996 and integrated on the basis of digesting and assimilating. In 1997, Galanz set up research and development department, and set up technological development organization in U.S.A. in 1998, beginning to move toward the new stage of independent development and cooperation.

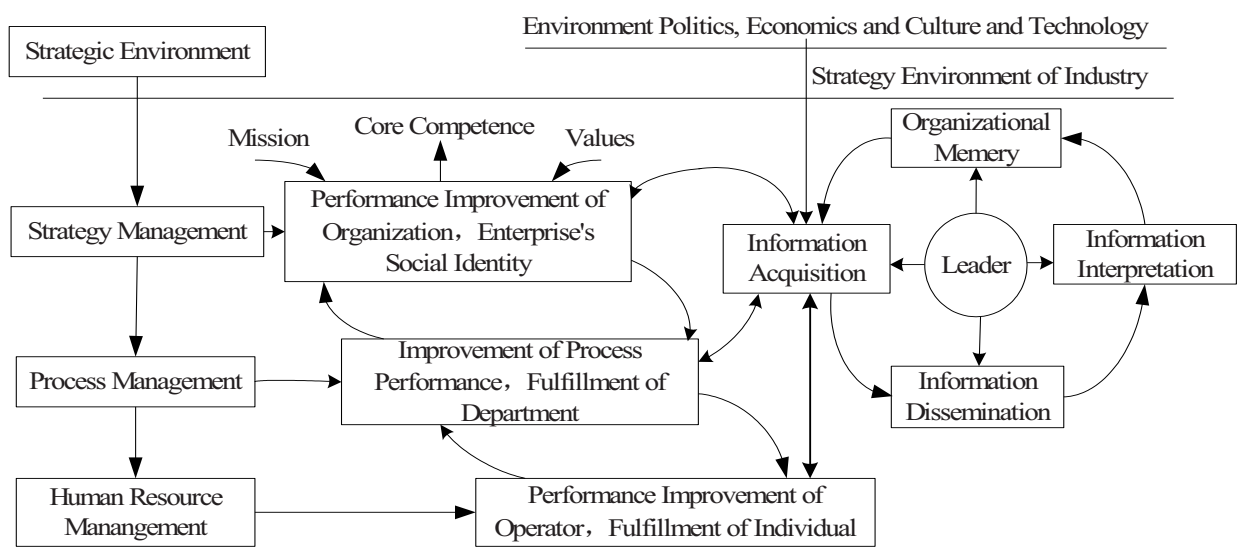

Fig. 3: Model of Performance Management with Synergy of Organizational Learning. 


\section{Strategic Performance Management System with Synergy OL}

Currently, there are a lot of research on organizational learning performance management ,Such as Performance Pyramid (McNair, C.J., Lynch, R.L. And Cross, K.L., 1990 $)^{[6]}$. Ge Jin ${ }^{[7]}$ pointed out that the management of the learning process can be researched from the individual subsidiaries, unit mix and the level of the entire network.
Organizational learning have different management priorities in different stages of internationalization. We found that few researchers take the organizational learning as a factor of performance evaluation in different stages of development. This paper analyzes the organizational learning performance indicators of multinational enterprises from four stages .Different development stage, firm has different strategy and strategic performance measurement correspondingly shown as in Tab.1.

\begin{tabular}{|c|c|c|c|}
\hline Stage & $\begin{array}{l}\text { Strategy } \\
\text { Goal }\end{array}$ & Strategy Choice & Performance Measurement \\
\hline \multirow{3}{*}{$\begin{array}{l}\text { Domestic } \\
\text { Stage }\end{array}$} & \multirow{3}{*}{$\begin{array}{l}\text { Domestic } \\
\text { market } \\
\text { focal } \\
\text { strategy }\end{array}$} & \multirow{3}{*}{ 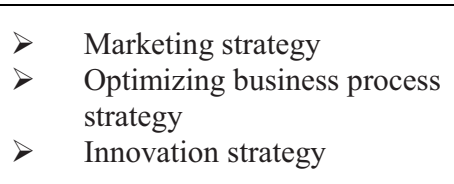 } & Financial measures \\
\hline & & & $\begin{array}{c}\text { Business and process } \\
\text { measures }\end{array}$ \\
\hline & & & $\begin{array}{c}\text { Technology innovation } \\
\text { measures }\end{array}$ \\
\hline \multirow{6}{*}{$\begin{array}{l}\text { Multinational } \\
\text { Stage }\end{array}$} & \multirow{6}{*}{$\begin{array}{l}\text { Domestic } \\
\text { market } \\
\text { focal } \\
\text { strategy of } \\
\text { economy of } \\
\text { scale }\end{array}$} & \multirow{6}{*}{$\begin{array}{ll}> & \text { Low cost strategy } \\
> & \text { Diversification strategy } \\
> & \text { Difference product strategy } \\
> & \text { Culture strategy } \\
> & \text { Reconstructing strategy of } \\
\text { business process } \\
>\quad \begin{array}{l}\text { Technology innovation } \\
\text { strategy }\end{array}\end{array}$} & Financial measures \\
\hline & & & Domestic OL measures \\
\hline & & & Marketing measures \\
\hline & & & $\begin{array}{c}\text { Environment protection } \\
\text { measures }\end{array}$ \\
\hline & & & $\begin{array}{c}\text { Business and process } \\
\text { measures }\end{array}$ \\
\hline & & & $\begin{array}{c}\text { Technology innovation } \\
\text { measures }\end{array}$ \\
\hline \multirow{6}{*}{$\begin{array}{c}\text { Transnational } \\
\text { Stage }\end{array}$} & \multirow{6}{*}{$\begin{array}{l}\text { Focal } \\
\text { strategy of } \\
\text { area market }\end{array}$} & \multirow{6}{*}{ 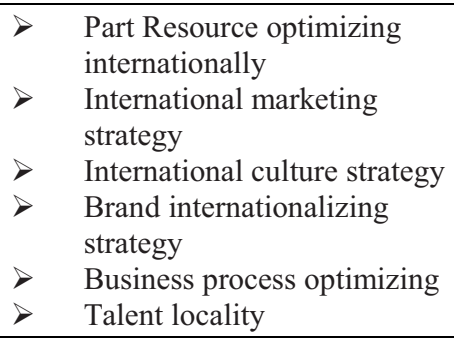 } & Financial measures \\
\hline & & & Transnational OL measures \\
\hline & & & Marketing measures \\
\hline & & & $\begin{array}{c}\text { Environment protection } \\
\text { measures }\end{array}$ \\
\hline & & & $\begin{array}{c}\text { Business and process } \\
\text { measures }\end{array}$ \\
\hline & & & $\begin{array}{c}\text { Technology innovation } \\
\text { measures }\end{array}$ \\
\hline \multirow{6}{*}{ Global Stage } & \multirow{6}{*}{$\begin{array}{l}\text { Global } \\
\text { focal } \\
\text { strategy }\end{array}$} & \multirow{6}{*}{$\begin{array}{ll}> & \begin{array}{l}\text { Resource optimizing } \\
\text { globally }\end{array} \\
>\quad & \begin{array}{l}\text { Global marketing } \\
\text { (production) network system }\end{array} \\
\text { strategy }\end{array}$} & Financial measures \\
\hline & & & Global OL measures \\
\hline & & & Marketing measures \\
\hline & & & $\begin{array}{c}\text { Environment protection } \\
\text { measures }\end{array}$ \\
\hline & & & $\begin{array}{c}\text { Business and process } \\
\text { measures }\end{array}$ \\
\hline & & & $\begin{array}{c}\text { Technology innovation } \\
\text { measures }\end{array}$ \\
\hline
\end{tabular}

Table 1: Multistage Performance Measurement system. 
During the course of dealing in at home, the strategic objectives of enterprises are to meet demand of domestic market. Marketing strategy and quality management are often adopted. Haier introduced the advanced production line from Germany in initial stage, advances total quality management etc. performance measurement includes the measures of three aspects: Financial measures, business process measures and technological innovation measures. After firm fully developing at home, economy of scale occurs and abundant experience is accumulated. Difference of the overseas market being realized, firm establishes international department. Firms often adopt low cost strategy, diversification strategy and culture strategy and etc. performance measurement at this stage includes: Financial measures, domestic organizational learning measure, market measures,measures of environmental protection and technological innovation measures. At the third stage of transnational stage, enterprises adopt the strategic goal of regional centre; divide overseas market into different areas. Enterprises often adopt international marketing strategy, resource optimization and corporate culture internationalization strategy, talent locality and ect. Performance measurement of this stage includes financial measures, transnational organizational learning measures, market measures, measures of environmental protection, measures of business process and technological innovation measures. At the fourth stage, enterprises adopt the strategic goal of the global centre, Strategy of enterprises can be described as "thinking from whole world, taking action in area". enterprises often adopt strategy of production factors disposing and optimizing within whole world, strategic alliance, global cultural strategy and etc.. performance measurement include financial measures, the global organizational learning measures, measures of environmental protection, measures of business process, measures of technological innovation. According to one's own strategic goal, Haier, TCL and Galanz have accelerated internationalized paces. Haier began its internationalization strategy in 1999, strategy of three $1 / 3$ that producing and selling $1 / 3$ at home, producing at home and selling abroad $1 / 3$, producing and selling $1 / 3$ abroad. Haier adopting global strategy entering into difficult market first in developed countries, such as U.S.A., Germany, Japan, etc. TCL followed global strategy from easy to difficult conversely, TCL registered the branch company in Vietnam in 1999, began the internationalized process. Galanz started the global strategy in 1998, the European branch company of Galanz was established in 1998, in the next two years, Galanz developed from South Asia to Africa, from Europe to Oceania, cross over from South America to North America.

\section{Conclusion}

Performance management is the important tool of enterprise's strategy management control. Organizational learning is key that the enterprises form core competence and keep competitive. Organizational learning advances performance management control.

\section{References}

[1] Simons, Robert. Strategic orientation and top management attention to control systems [J]. Strategic Management Journal, 1991(12): 4962.

[2] Kanji, G.K. Measurement of Business Excellence [J].Total Quality Management, 1998(9):633-643. 
[3] Kostas N. Dervitsiotis. The Design of Performance Measurement Systems for Management Learning [J]. Total Quality Management, 2004, Vol. 15, No. 4: 457-473.

[4] Argyris and Schon (1978). Organizational Learning: A Theory of Action Perspective [M]. AddisonWesley Publishing Company,Reading,MA.1978:7-18

[5] Huber. Organization Learning: The Contributing Processes and Literatures $[\mathrm{J}]$. Organization Science, 1991(2):88-115.

[6] McNair, C.J., Lynch, R.L. and Cross , K.L. Do financial and nonfinancial performance measures have to agree? [J]Management Accounting 1990(75):28-36.

[7] Ge Jin. Knowledge transfer and organizational learning in the process of internationalization[J].China Soft Science,2002,(01): 57-60. 